\title{
Peran Dokter Gigi Keeil Dalam Peningkatan Perilaku Hidup Sehat
}

\author{
Erlina Sih Mahanani1*, Likky Tiara Alphianti ${ }^{1}$, Widyapramana Dwi Atmaja ${ }^{1}$, dan Hastoro \\ Pintadi1 \\ 1. Progam Studi Kedokteran Gigi, Fakultas Kedokteran dan Ilmu Kesehatan, Universitas Muhammadiyah Yogyakarta \\ Email: erlina.sih@umy.ac.id \\ DOI: $10.18196 / p p m .39 .114$
}

\begin{abstract}
Abstrak
Kegiatan promosi dan preventif kesehatan sangat diperlukan untuk mengubah perilaku hidup bersih dan sehat. Upaya memaksimalkan dan memanfatkan peran dokter kecil yang dibentuk di Dusun Pendul sebagai motor penggerak untuk memengaruhi dan membiasakan perilaku hidup bersih dan sehat. Program pengabdian kemitraan masyaraklat dilakukan di Dusun Pendul, Argorejo, Sedayu, Bantul dilakukan dengan memanfaatkan dokter gigi kecil sebagai motor penggerak perilaku hidup bersih dan sehat dengan mengajari teman-temannya dan memengaruhi keluarganya. Metode yang dilakukan adalah penyuluhan melalui dokter gigi kecil dengan bahasanya sendiri, bimbingan belajar yang disertai membiasakan perilaku hidup bersih dan sehat seperti cuci tangan, bersih diri, membuang sampah, serta memasang poster-poster promosi kesehatan dan permainan lagu yang bertema kesehatan. Dalam kegiatan ini anak-anak akan didampingi oleh pendamping anak atau orang tua yang sekaligus menjadi sasaran penyuluhan kesehatan gigi serta perilaku hidup bersih dan sehat. Hasil kegiatan ini ternyata dapat memengaruhi kebiasaan hidup bersih dan sehat pada abak-anak dan pendamping anak-anak.
\end{abstract}

Kata Kunci: dokter gigi kecil, perilaku hidup bersih dan sehat, penggerak, preventif

\section{Pendahuluan}

Perilaku hidup bersih dan sehat populer di masyarakat dengan singkatan PHBS. Kegiatan ini merupakan upaya membangun lingkungan sehat dalam masyarakat dengan membentuk perilaku kesehatan anggota keluarga maupun setiap individu sehingga dapat berperan aktif dalam kegiatan- kegiatan kesehatan di masyarakat (Sondakh, Joseph, \& Koem, 2015). Pembangunan bidang kesehatan di Indonesia bertujuan untuk meningkatkan kesadaran, kemauan, dan kemampuan hidup sehat bagi setiap individu di Indonesia. Hal ini diharapkan akan mewujudklan peningkatan derajat kesehatan yang tinggi bagi masyarakat (Depkes RI, 2010). Perubahan sikap, pengetahuan, dan perilaku terhadap kebersihan dan kesehatan dapat dipengaruhi oleh suatu sistem promosi kesehatan (Carmen, 2008).

Usia anak sekolah merupakan usia yang menentukan perkembangan saat dewasa nanti. Tingkat Sekolah Dasar adalah masa tumbuh kembang anak dan merupakan periode yang dapat ditemukan berbagai masalah kesehatan yang perlu diatasi, dijaga, dan dilindungi. Masa ini merupakan masa anak-anak belajar dan potensial untuk diberi pengaruh positif guna membentuk kesadaran akan kesehatannya (Dermawan 2012; Keating and Hertzman, 1999). Anak-anak akan mudah menerima pengajaran yang diberikan secara menarik, mampu mengklasifikasikan informasi, dan dapat diajari keterampilan melakukan sesuatu yang bermanfaat untuk kesehatannya (Sylva, 1994).

Kader dokter kecil ini adalah individu yang teroganisasi dalam kurun waktu tertentu dan selama itu kualitasnya terus ditingkatkan guna mencapai suatu tujuan, yaitu peningkatan kualitas kesehatan gigi dan mulut. Dokter gigi kecil adalah golongan masyarakat usia sekolah (6-18 tahun) yang merupakan bagian yang besar dari penduduk Indonesia (+29\%). Diperkirakan 50\% dari jumlah tersebut adalah anak-anak sekolah yang masih dalam taraf pertumbuhan dan perkembangan sehingga masih mudah dibina dan dibimbing (Entjang, 2000). Dalam pengabdian ini akan berfokus pada usia sekolah dasar yaitu $8-12$ tahun. 
Fakultas Kedokteran dan Ilmu Kesehatan Universitas Muhammadiyah Yogyakarta merupakan salah satu fakultas yang juga menjalankan visi dan misi Universitas Muhammadiyah Yogyakarta. Untuk menuju fakultas yang "unggul dan islami", perlu adanya usaha dan program yang tepat. Salah satu acuannya adalah Tri Dharma Perguruan Tinggi, yaitu Pendidikan, Penelitian, dan Pengabdian kepada Masyarakat. Bekerja sama dengan mahasiswa Kedokteran Gigi dalam Himpunan Mahasiswa Kedokteran Gigi (HIMAKAGI) melakukan usaha promosi dan preventif kepada anak-anak usia sekolah dasar Dukuh Pendul, Kelurahan Argorejo, Kecamatan Sedayu, Kabupaten Bantul untuk meningkatkan perilaku hidup bersih dan sehat. Dukuh Pendul yang terdiri atas $200 \mathrm{KK}$ sebagian besar penduduknya adalah buruh tani, buruh bangunan, dan pekerjaan lainnya. Penyuluhan tentang kesehatan dan PHBS diperoleh dari petugas puskesmas yang bertugas ke daerah ini sehingga kesadaran dan pengetahuan masyarakat masih sangat kurang.

Pengabdian masyarakat ini mengusung kegiatan promosi dan preventif dalam rangka meningkatkan dan mendorong masyarakat untuk memiliki kesadaran perilaku hidup bersih dan sehat melalui kader dokter gigi kecil. Dokter gigi kecil akan memengaruhi teman-teman seusianya anggota keluarganya, termasuk orang tuanya yang ikut mendampingi dalam kegiatan dokter gigi kecil. Pembinaan dan pengajaran melalui dokter gigi kecil sebagai motor penggerak diharapkan akan diterapkan di kehidupan sehari-hari oleh warga sehingga aspek-aspek seperti kesehatan maupun pendidikan dapat meningkat dan dapat menambah kualitas hidup warga.

\section{Metode Pelaksanaan}

A. Metode Pelaksanaan Metode yang dilakukan dalam pengambian masyarakat ini sebagia berikut.

1. Penyuluhan mengenai Perilaku Hidup Bersih dan Sehat (PHBS) tentang kebersihan diri, lingkungan, dan makanan bergizi menggunakan alat bantu peraga yang dapat membantu pemahaman kepada kader dokter gigi kecil. Kemudian dokter gigi kecil mempraktikkan memberi penyuluhan dengan bahasanya kepada teman-teman di TPA Al-Asher.

2. Praktik perilaku hidup bersih dan sehat untuk kader dokter gigi kecil dan anak-anak.

3. Melibatkan orang tua pendamping anak dalam kegiatan sehingga ikut terpapar.

4. Masuk terlibat dalam kegiatan TPA anak-anak di Dusun Pendul dengan didahului pembiasaan perilaku hidup bersih dan sehat.

5. Evaluasi yang dilakukan dengan pengisian kuisioner dan pemeriksaan OHI-S kepada anak-anak.

6. Aktivitas santai dengan mengobrol ringan sambil memberikan edukasi melalui permainan dan melantunkan lagu bertema kebersihan.

7. Melakukan belajar bersama dan pendampingan mengerjakan PR pelajaran sekolah dengan dimulai pembiasaan perilaku hidup bersih dan sehat.

8. Pelatihan PPPK dan tanaman obat.

B. Sasaran dan Lokasi

1. Anak-anak TPA Masjid Al-Asher di dampingi remaja masjid dan orang tua anak-anak.

2. Lokasi di Masjid Al Asher, Dukuh Pendul, Argorejo, Sedayu, Bantul,Yogyakarta.

\section{Hasil dan Pembahasan Kegiatan Pertama}

Kegiatan hari pertama, Sabtu 7 Desember 2019, pengabdian masyarakat peran dokter gigi kecil dalam peningkatan perilaku hidup sehat dilakukan dengan pembukaan secara 
sederhana yang dihadiri oleh Kepala Dukuh, Kepala TPA Al-Asher, Remaja Desa, dan anakanak TPA Al-Asher. Kegiatan dimulai dengan pembacaan ayat suci Al-Qur'an secara bersamasama dan dilanjutkan pemaparan rencana kegiatan dan sambutan-sambutan. Kemudian, dilanjutkan dengan melakukan penyuluhan mengenai perilaku hidup bersih dan sehat secara terperinci tentang kebersihan diri, lingkungan, dan makanan bergizi. Kegiatan ini diharapkan mampu menambah wawasan anak-anak dan meningkatkan pola hidup sehat mereka sehingga mampu berperilaku bersih dan sehat. Hal ini juga menjadi tolok ukur keberhasilan kegiatan yang dilakukan sebelum dan sesudah kegiatan ini dilaksanakan.

Materi yang diberikan berupa power point yang menarik dengan gambar-gambar interaktif yang memudahkan anak-anak untuk memahami dan mengingat (Sadiman, 2002). Anak-anak TPA peserta penyuluhan tampak antusias dan memperhatikan materi yang disampaikan. Setelah penyuluhan, dilanjutkan dengan praktik perilaku hidup bersih dan sehat yang dimulai dengan kebersihan diri. Praktik sederhana memotong kuku dan mencuci tangan dengan cara yang benar. Kegiatan praktik kebersihan diri ini disertai dengan komunikasi aktif dan santai dengan anak-anak sambil terus mengingatkan dan menyampaikan eduksi kesehatan dengan metode permainan serta melantunkan lagu yang bertema kesehatan, seperti pada Gambar 1. Hal ini diharapkan dapat membantu anak-anak mengingat edukasi yang disampaikan (Notoatmojo, 2003; Jourdan, 2011). Selain itu, hal ini untuk menciptakan keakraban antara anak-anak dan pelaksana pengabdian sehingga ketika dilakukan kegiatan berikutnya berupa pemeriksaan kebersihan mulut dengan metode pemeriksaan Oral Hygiene Indeks Simplified (OHI-S) anak-anak tidak merasa canggung ataupun takut untuk diperiksa. Setelah selesai diperiksa, anak-anak diberi sedikit edukasi mengenai kebersihan gigi dan mulut serta pentingnya periksa ke dokter gigi. Kegiatan hari pertama diakhiri dengan evaluasi yang dilakukan dengan pengisian kuesioner.

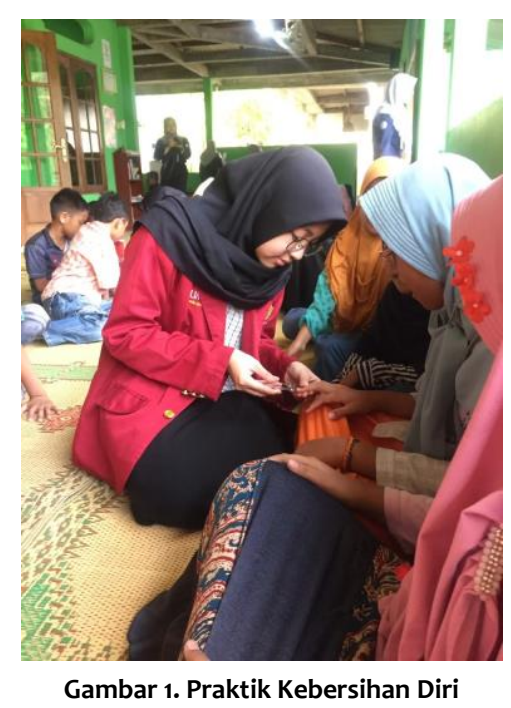

\section{Kegiatan Kedua}

Dua minggu kemudian, Sabtu 21 Desember 2019, kegiatan kedua dilaksanakan. Kegiatan dimulai dengan berdoa dan membaca Ayat Suci Al-Qur'an bersama-sama. Pada kegiatan kali ini, anak-anak TPA dibagi menjadi beberapa kelompok kecil berdasarkan tingkatan kelas sekolahnya, dari TK sampai SD kelas 6. Beberapa anak yang sudah kelas 5 dan 6 SD telah dipilih menjadi kader dokter gigi kecil pada program pengabdian sebelumnya. 
Kelompok anak-anak kelas 6 SD mengikuti program "Tanya PR", yaitu program yang memberikan kesempatan anak-anak untuk belajar dan bertanya mengenai materi pelajaran di sekolah seperti pada Gambar 2. Pada kesempatan ini, pelajaran yang diberi bimbingan adalah Mata Pelajaran Bahasa Inggris. Media yang digunakan berupa media visual, yaitu poster dan soal-soal latihan bergambar (Gambar 3).

Sedangkan pada kelompok dokter gigi kecil diberikan materi pelatihan anatomi gigi dasar, cara menyikat gigi yang baik dan benar, serta penggunaan dental floss dan pengenalan beberapa alat pemeriksaan gigi dasar minimalis (Gambar 4). Setelah selesai penyampaian materi, dokter gigi kecil diberi kesempatan untuk berlatih memberikan penyuluhan kepada teman-temannya. Kegiatan ini pun disertai remaja masjid dan orang tua anak-anak sehingga secara tidak langsung orang tua ikut terpapar penyuluhan tentang perilaku hidup bersih dan sehat serta kesehatan gigi. Kegitan kedua ini diakhiri dengan kuis tanya jawab tentang materi penyuluhan. Kegiatan ini diikuti oleh 33 anak-anak. Kegiatan ini diharapkan dapat memberikan pelajaran dan mampu mengasah anak-anak agar dapat mengingatkan satu sama lain mengenai kebersihan gigi dan mulut.

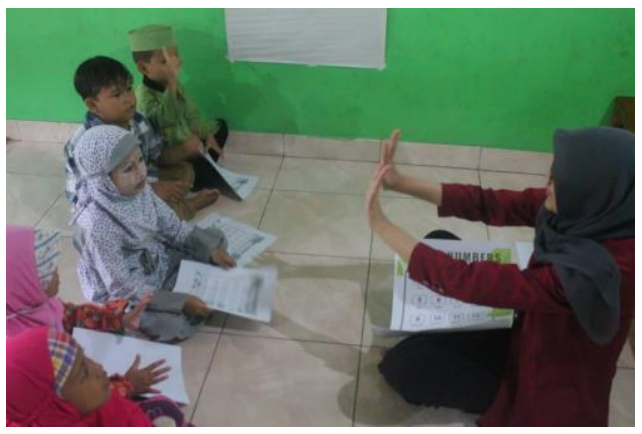

Gambar 2. Program “Tanya PR”, Pendampingan Belajar
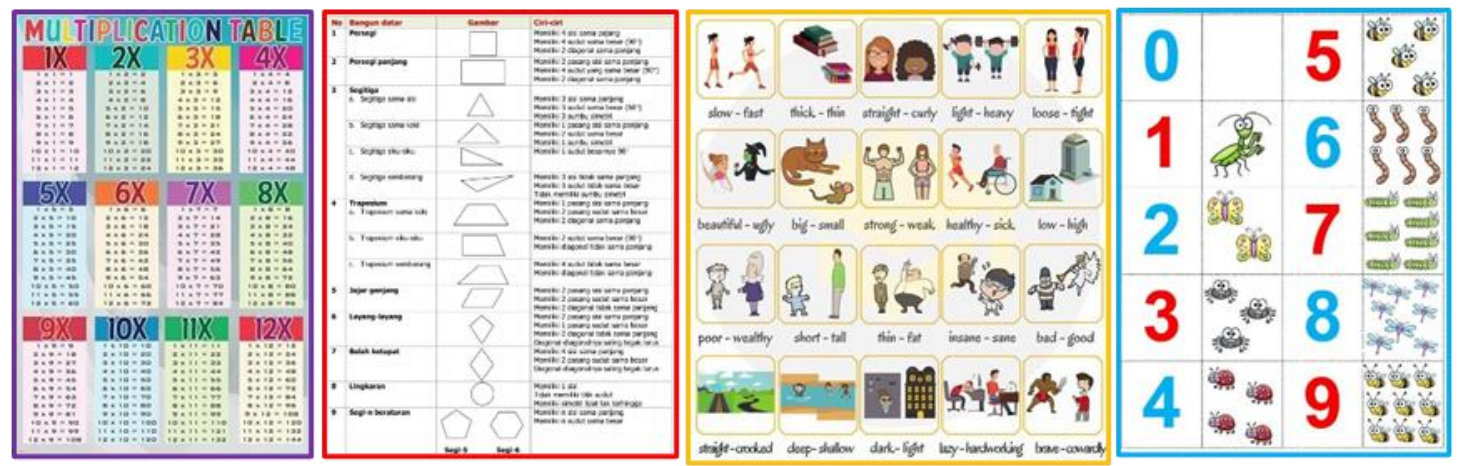

Gambar 3. Poster-poster yang Digunakan untuk Kegiatan “Tanya PR"

\section{Kegiatan Ketiga}

Berikutnya, Sabtu, 8 Februari 2020, yaitu kegiatan pengenalan penyakit gigi dan mulut beserta pencegahan dan pengobatannya. Kegiatan ini masih dilakukan secara berkelompok berdasarkan tingkatan kelas sekolahnya seperti kegiatan kedua. Kali ini, kegiatan "Tanya PR" masih dilanjutkan untuk pelajaran matematika. Kegiatan ini dibarengi dengan permainan agar tidak tegang dan rileks disertai dengan mengedukasi anak-anak dengan lagu-lagu yang Islami dan bertema kebersihan.

Sedangkan pada kelompok dokter gigi kecil diberikan materi mengenai macam-macam penyakit gigi dan mulut serta tanaman obat untuk mencegah dan mengobati penyakit gigi dan mulut. Pada kelompok ini diberikan materi dengan media visual berupa poster dan gambargambar yang dapat menggambarkan penyakit gigi dan mulut, dimulai penyebab hingga 
terjadinya penyakit tersebut secara sederhana. Kemudian, dilanjutkan dengan penyampaian materi oleh dokter gigi kecil kepada teman-teman di TPA Al-Asher.

Dalam kegiatan ini, anak-anak tampak senang, bersemangat dan menunjukan adanya perubahan perilaku hidup bersih dan sehat yang sudah diajarkan sebelumnya. Hal-hal yang kecil pun kami perhatikan mulai dari cuci tangan, potong kuku, dan menyikat gigi sudah dilaksanakan oleh sebagian besar anak-anak. Selanjutnya diakhiri dengan kuis dan permainan di akhir acara. Sebelum pulang dilakukan pembagian hadiah dan doa bersama serta pembagian snack kepada anak-anak. Kegiatan ini diikuti oleh 20 anak-anak. Harapannya kegiatan ini mampu meningkatkan pengetahuan anak-anak mengenai pelajaran yang diberikan dan macam penyakit gigi dan mulut beserta pencegahan dan pengobatannya.

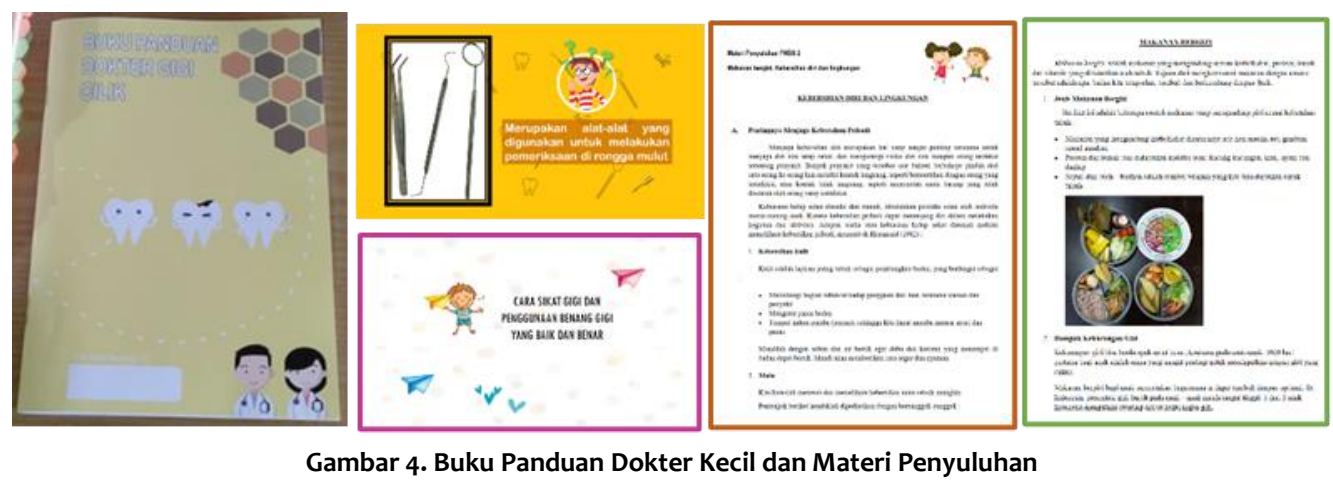

\section{Kegiatan Keempat}

Kegiatan keempat dilaksanakan pada hari Sabtu, 29 Februari 2020, yaitu pengenalan tentang Pertolongan Pertama Pada Kecelakaan (PPPK). Seperti pertemuan sebelumnya, program "Tanya PR" tetap berjalan dengan mata pelajaran IPA. Bimbingan belajar diberikan dengan media print out materi dan poster. Anak-anak sangat antusias dalam hal ini dan sering mengajukan pertanyaan kepada tim pengajar dari pelaksana pengabdian. Kegiatan ini juga masih disertai dengan permainan dan menyanyikan lagu-lagu yang bertema Islami dan kebersihan untuk membentuk pola pikir sehat dan bersih serta Islami.

Materi yang diberikan kepada kelompok dokter gigi kecil berupa pengenalan alat dan bahan PPPK (Pertolongan Pertama pada Kecelakaan) dan cara pertolongan pertama apabila mengalami luka. Dalam kegiatan ini, materi mengenai tanaman obat juga diberikan dan nantinya tanaman obat tersebut akan di tanam di halaman masjid. Tim pelaksana pengabdian mengajarkan cara perawatan tanaman obat, pemanfaatan, dan cara pengolahan sampai dapat menjadi obat yang berkhasiat. Setelah itu, dokter gigi kecil juga diberi kesempatan untuk menyampaikan materi PPPK dan tanaman obat kepada teman-teman TPA-nya.

Di penghujung kegiatan keempat ini, anak-anak diberikan kuis dari materi PPPK dan tanaman obat. Anak yang bisa menjawab dengan tepat akan diberi hadiah. Kegiatan ini diharapkan dapat menambah wawasan anak-anak mengenai PPPK dan cara pengaplikasiannya.

\section{Kegiatan Penutup Saat Pandemi}

Kegiatan pada saat terjadinya pandemi memerlukan pengubahan setting kegiatan. Penutupan yang awalnya akan kami adakan lomba-lomba untuk anak-anak akhirnya kami ubah dengan berpamitan, memberikan bingkisan untuk semua anak-anak, penyerahan perpustakaan mini yang terdiri atas rak buku dan buku-buku kesehatan, serta penyampaian bantuan untuk perilaku kebersihan diri dan sembako (Gambar 6). Bantuan kami serahkan kepada Kepala Dukuh Pendul dan Ketua TPA Al-Asher. Kegiatan ini dilakukan dengan mematuhi protokol kesehatan. Keadaan pandemi membuat anak-anak lebih mudah untuk melakukan protokol 
kesehatan karena sudah terbiasa dengan perilaku hidup bersih dan sehat, terbiasa melakukan cuci tangan, dan kebersihan diri (Gambar 5).

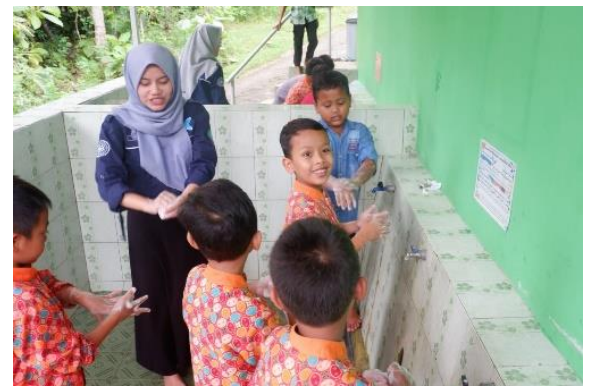

Gambar 5. Cuci Tangan Sebelum Kegiatan, Salah Satu Perilaku Hidup Bersih dan Sehat
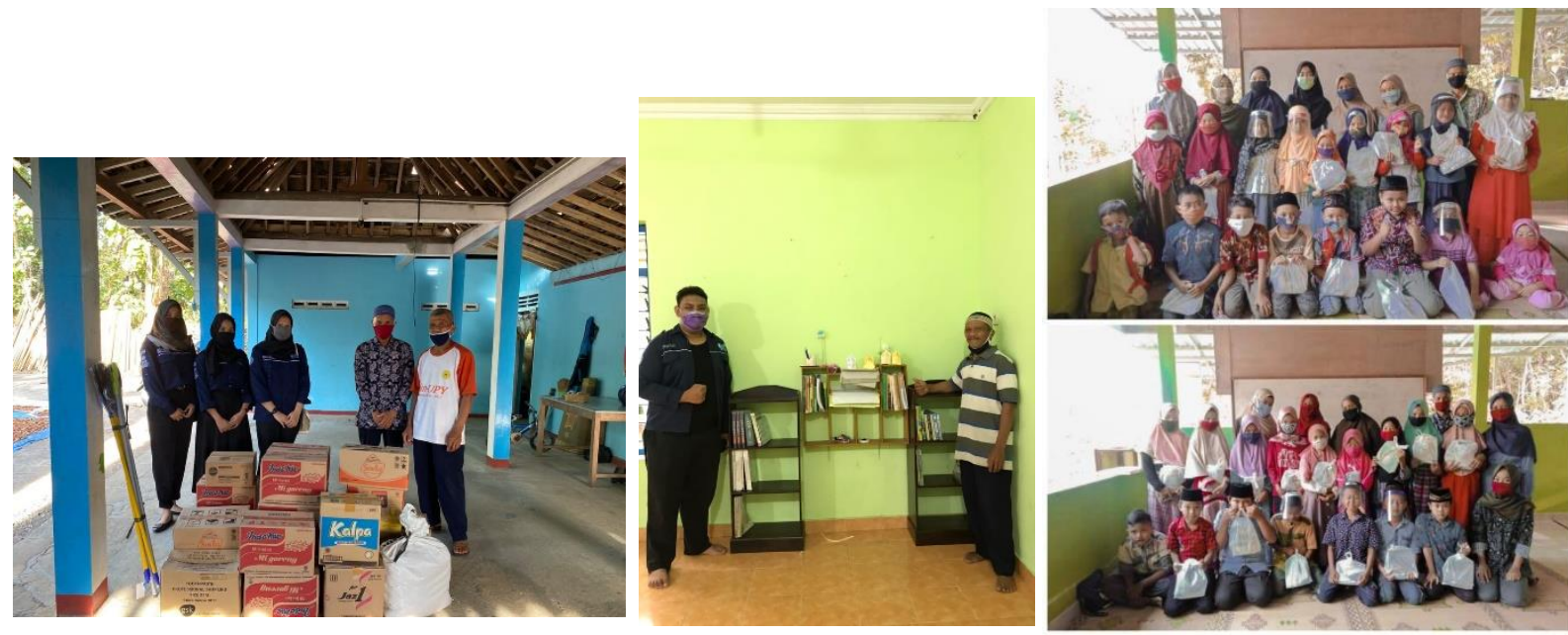

Gambar 6. Penyerahan Bantuan dan Bingkisan untuk Anak-anak

Kegiatan pengabdian masyarakat pada anak-anak Dukuh Pendul, Desa Argorejo ini dapat memberikan pengaruh terhadap perilaku hidup bersih dan sehat (Gambar 5, menunjukkan perubahan perilaku anak-anak) dengan pendekatan kegiatan-kegiatan TPA, belajar besama, dan penyuluhan. Pembiasaan perilaku hidup bersih dan sehat yang dilakukan dengan kegiatankegiatan santai terbukti menjadi pola perilaku yang terus dilakukan. Hal ini sesuai dengan teori dari Lawrence Green, yaitu perilaku seseorang dipengaruhi 3 faktor. Pertama adalah faktor pengetahuan, kedua adalah faktor pendukung yang berupa fasilitas, dan ketiga adalah faktor pendorong terwujudnya suatu perilaku (Notoatmodjo, 2014). Pengetahuan anak-anak diperoleh dari materi penyuluhan yang diberikan tim pelaksana pengabdian termasuk dengan metode permainan (Saint and Nutbeam, 2011). Faktor pendukung berupa fasilitas yang disediakan tim pengabdian, berupa alat bersih diri dan sabun cuci tangan. Faktor pendorong yang merupakan faktor ketiga adalah dengan pembiasaan di setiap kegiatan dan promosi yang tepat dan sesuai untuk usia anak-anak memberikan dorongan yang kuat kepada anak-anak untuk membiasakan diri berperilaku hidup bersih dan sehat (Carmen, 2008).

Pembentukan kader dokter gigi kecil yang dilatih dan mampu menularkan pengetahuan kepada teman-temannya memberi pengaruh yang besar sebagai penggerak komunitas seusianya (Houwink, 1993). Selain itu, pelibatan orang tua dalam mendampingi atau menunggui anakanak selama berkegiatan memberi pengaruh ikut terpaparnya orang tua akan promosi kesehatan yang diberikan kepada anak-anak. Hal ini diharapkan akan memberi pengaruh pada perilaku hidup bersih sehat di keluarga masing-masing.

\section{Simpulan}


Pengabdian masyarakat dengan melatih kader dokter gigi kecil dapat menggerakkan teman-teman seusianya untuk membiasakan perilaku hidup bersih dan sehat. Selain itu, kegiatan yang melibatkan orang tua dalam mendanpingi anak-anaknya memberi pengaruh positif dalam perilaku hidup bersih dan sehat dalam keluarganya.

\section{Ucapan Terima Kasih}

Terima kasih kepada LP3M UMY atas pendanaan pengabdian masyarakat melalui Program Kemitraan Masyarakat tahun 2019.

\section{Daftar Pustaka}

Carmen, A. (2008). Changes in Attitudes, Knowledge, and Behaviour Associated with Implementing a Comprehensive School Health Program in a Province of China. Health Education, Res Volume 23, Issue 6: 1049-1067.

Departemen Kesehatan Republik Indonesia. (2010). Pedoman PHBS Tatanan Sekolah. Jakarta: Departemen Kesehatan Republik Indonesia.

Dermawan, D. (2012). Buku Ajar Keperawatan Komunitas Edisi 1. Yogyakarta: Gosyen Publishing.

Entjang, I. (2000). Ilmu Kesehatan Masyarakat. Jakarta: PT Citra Aditya Bakti.

Houwink, B. (1993). Ilmu Kedokteran Gigi Pencegahan. Yogyakarta: Gajah Mada University Press.

Jourdan, D. (2011). Health Education in Schools. The Challenge of Teacher Training Saint Denis : Inpes: $144 \mathrm{p}$.

Keating D.P. \& Hertzman, C. (1999). Developmental Health and the Wealth of Nations: Social, Biological, and Educational Dynamics. New York: Guilford Press.

Notoatmojo, S. (2003). Pendidikan dan Perilaku Kesehatan. Jakarta: Rineka Cipta.

Notoatmodjo, S. (2014). Kesehatan Masyarakat Ilmu dan Seni. Jakarta: Rineka Cipta.

Sadiman. (2002). Media Pendidikan. Surabaya: Airlangga University Press.

Saint-Leger L., Nutbeam D. (2000). Health promotion in schools. In : IUHPE. The Evidence of Health Promotion Effectiveness. Shaping Public Health in a New Europe. Part two : evidence book. Vanves: IUHPE: p. 110-133.

Koem, Z.A.R., Joseph, B., \& Sondakh, R.C. (2015). Hubungan antara Pengetahuan dan Sikap dengan Perilaku Hidup Bersih dan Sehat (PHBS) pada Pelajar di SD Inpres Sukur Kecamatan Airmadidi Kabupaten Minahasa Utara. PHARMACON (Jurnal Ilmiah Farmasi-UNSRAT), Vol. 4 (4), p 290-294.

Sylva, K. (1994). School Influences on Children's Development. Journal of Child Psychology and Psychiatry and Allied Disciplines, Vol. 35, No. 1: p. 135- 170. 